\title{
Aikuiskasvatuksen tutkijan tehtävästä
}

\author{
JUHASUORANTA
}

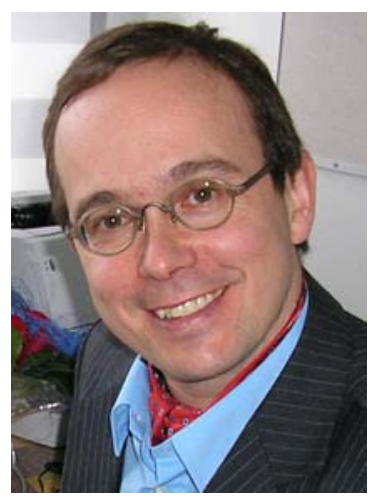

\begin{abstract}
"Kriittisen ajattelun liikkeen tavoitteen on oltava inhimillistymisessä - joka on ihmisen historiallinen päämäärä. Täyden ihmisyyden tavoittelu ei kuitenkaan voi toteutua eristyksissä tai henkilökohtaisesti, vaan toverillisesti ja solidaarisesti." - (Freire 2005, 92)
\end{abstract}

ampereen yliopiston aikuiskasvatuksen professori, filosofi Urpo Harva, piti jäähyväisluentonsa vuonna 1973 otsikolla Akateemisen opettajan tehtävä (Harva 1974). Siinä hän nosti esille kysymyksiä, joista on keskusteltu myös viime aikoina huolestuneeseen ja ajoittain kriittiseen sävyyn. Hän puhui yliopiston kriisistä, joka johtui kahdesta seikasta. Ensimmäinen näistä oli yliopistojen muuttuminen ammatillisiksi oppilaitoksiksi, joiden opetus perustui käytännöllisen hyödyn tavoitteluun eikä todellisuuden ilmiöiden totuudelliseen tarkasteluun. Toinen yliopistokriisin aiheuttaja oli opetuksen hajoaminen yhä kapeammiksi, toisistaan erillään oleviksi erityistieteiksi.

Harva tiesi, etteivät yliopiston ongelmat olleet syntyneet hänen aikanaan, vaan samaisista kysymyksistä kirjoitti jo saksalaisfilosofi Immanuel Kant nimittäen oman alansa spesialisteja yksisilmäisiksi kykloopeiksi. Harva rohkaisi opettajia kehittämään itsessä ja toisissa hengenyhteydelle perustuvaa todellista vapaata akateemisuutta. Tässä tehtävässä oli Harvan sanoin voitettava kaksi vaikeutta: "Toinen on tiedon rannaton valtameri, jolla helposti purjehtii harhaan yrittäessään tähytä yli oman suppean tiedonalansa rajojen". Ja toinen vaara, jolle jokainen on altis, "on se ettei pysty näkemään olevaisuutta sellaisena kuin se on, vaan jonkin idolan tai ideologian vääristämänä". - Idolalla Harva viittasi ajattelua estäviin ennakkoluuloihin.

Mutta onko tällaisten ennakkoluulojen ja ideologisten vääristymien välttäminen ylipäätään mahdollista? Harva tuskin olisi hyväksynyt nykyistä käsitystä, jonka mukaan kaikki ajattelu niin sanottu tieteellinenkin - on viime kädessä ideologista, ja jonka mukaan poliittinen, pedagoginen ja tieteellinen läpäisevät toisensa.

Jos tämä ajatus oli Harvalle vieras, on se eräs oman tutkimustyöni lähtökohta. En näe tiedettä erillään tutkimuksen tekijästä enkä myöskään erillään niistä yhteiskunnallisista yhteyksistä, joissa elämää eletään milloin rakastaen ja huolta pitäen, milloin yhteiskunnallisesta hegemoniasta kamppaillen.

\section{Kriittinen aikuiskasvatus}

Näitä kysymyksiä tieteen yhteiskuntapoliittisista yhteyksistä pidetään tärkeinä varsinkin kriittisen teorian mukaisessa radikaalissa aikuiskasvatuksessa (Brookfield 2005; Mayo 2003). Siihen on otettu vaikutteita marxilaisesta perinteestä, eritoten ajatuksesta, jonka mukaan todellisuus "ei ole lopullisten olioiden yhdistelmä, vaan prosessien yhdistelmä" (Engels 1886), eikä tutkijan tavoite pelkkä ilmiöiden kuvaaminen ja ymmärtäminen. Lisäksi hänen on pyrittävä vahvistamaan 
ihmisten itsetietoisuutta ja yhteiskunnallista muutosta epäkohtien poistamiseksi.

Kun Berliinin muuri murtui marraskuun 9. vuonna 1989 ja Neuvostoliitto-niminen sosialistiseksi kuviteltu valtio lakkasi olemasta paria vuotta myöhemmin, olettivat monet historian loppuneen. Niin kutsutun vapaan maailman opit levisivät pidäkkeettömästi kuin tsunami, pyyhkäisten mukanaan yhteiskunnalliseen toimijuuteen kuuluvat itsenäisen tahdonmuodostuksen, yhteistyön ja demokratian ihanteet länsimaiden ajatushorisontista (Misik 2006, 15). Maailmanlaajuiset aikakausimuutokset näkyivät myös aikuiskasvatuksen käytännöissä: yhä vähemmän painotettiin kriittisen tietoisuuden kehitysmahdollisuuksia ja yhä enemmän kilpailullisia ja hyötypainotteisia näkökohtia.

Laajemmassa merkityksessäyhteiskunnallisen tiedostamisen väitettiin liuenneen yleismaailmallisiin uhkakuviin ja väljähtyneisiin lohtuideologioihin, jotka lupasivat vain tuhon välttämisen mielikuvia. Oli siirrytty toivon utopioista "haaveettomuuden aikaan", jossa ei ollut sijaa inhimillisen kasvun kehitystarinoille saati kollektiivisesti voimistaville päämäärille. Jäljellä näyttivät jääneen vain kommunismin pelon korvannut terrorismin uhka, luonnonkatastrofien kauhut ja joukkoirtisanomisten epätoivo. (Ehrnrooth 1995.)

Mutta aivan kuin dialektisen metodin kaavaa noudattaen nämä aikakausikuvaelmat synnyttivät maailmanlaajuisen vastarinnan. Sinne tänne muodostui liikehdintää, joka yhtyessään laajempaan protestiaaltoon herätti uutta toivoa: lauseesta "toisenlainen maailma on mahdollinen" tuli oikeudenmukaisuutta ja kestävää kehitystä ajavan liikkeen, maailman sosiaalifoorumin, tunnuslause (ks. http://traviswinn.com/awip/). Uuden vuosituhannen alussa ihmiset alkoivat yhä selvemmin käsittää, ettei toivottomuus johda muuhun kuin epätoivon syvenemiseen ja kasvavaan vihaan. Etenkin ne, jotka toimivat globaalin oikeudenmukaisuuden ja rauhan puolesta, näkivät pilkahduksen "toivon hetkestä" (George 2002) ja tajusivat sen valossa aikaisempaa paremmin haaveettomuuspuheiden tyhjyyden ja sen, kuinka ne peittivät näkyvistä globaalin eriarvoisuuden mittasuhteet; esimerkiksi sen, että maailman 300 rikkaimman vuositulot ylittävät kolmen miljardin köyhimmän ansiot.

Tämänkaltaiset oikeudenmukaisuutta ja tasaarvoa koskevat "taistelukysymykset" kuuluvat kriittisen teorian mukaiseen aikuiskasvatuksen tutkimukseen ja poikkeavat jonkin verran niistä sitoutumattoman humanismin lähtökohdista, jotka luonnehtivat esimerkiksi Harvan ajattelua.

\section{Aikuiskasvatuksen politiikat}

Radikaalit aikuiskasvattajat ovat työskennelleet toisenlaisen maailman puolesta monissa sosiaalisissa liikkeissä ympäri maailman soveltaen toimintatutkimuksen ja yhteisökasvatuksen lähestymistapoja. Aikuiskasvatuksen opinnolliset käytännöt käsitetään yleensä poliittiseksi toiminnaksi, mutta käsitykset poliittisen toiminnan merkityksestä vaihtelevat (ks. Cervero \& Wilson 2001, 4-10). Poliittinen voi ensinnäkin tarkoittaa - iskulausetta "poliittinen on henkilökohtaista" tulkiten - aikuisoppijan ja hänen opinnollisten tavoitteidensa palvelemista. Olennaista on tällöin tietää, miten aikuisoppimista voidaan edistää (ja tehostaa).

Toiseksi poliittinen tarkoittaa aikuisopintoihin liittyvien käytännöllisen tavoitteiden täyttämistä. Näin aikuiskasvatus mielletään vallassa olevan koulutuspolitiikan ja sen mukaisten tehtävien suorittamiseksi, ja kysytään, kuinka tehdyt suunnitelmat saadaan toteutettua ja mitä niistä seuraa. Ja kolmannen käsityksen mukaan poliittinen viittaa yhteiskunnan rakenteellisiin epäkohtiin. Tämän "poliittinen on rakenteellista" näkökulman kannalta on olennaista tietää, kuinka yhteiskuntarakenteita ja niiden valta-asemia voidaan muuttaa aiempaa oikeudenmukaisemmiksi. Nämä poliittisen erilaiset merkitykset eivät sulje toisiaan pois, vaan rakennenäkökulma sisältää henkilökohtaisen kokemuksen ja henkilökohtainen poliittisen rakenneulottuvuuden, joka puolestaan näkyy aikuiskoulutuksen käytännöllisissä toimintamuodoissa, ja siinä kuinka valta näissä ilmenee.

Aikuiskoulutuksen valtiollisessa säätelyssä käytetään poliittista valtaa suuntaamalla resursseja tiettyihin lähinnä työllisyyden kannalta tarkoituksenmukaisiin kohteisiin. Näin eriytyneellä aikuiskoulutuksella harjoitetaan ihmisten elämään vaikuttavaa "biovaltaa". Mutta aikuiskasvatuksellinen valta liittyy myös inmistyöhön ja inmisten spontaanin kohtaamiseen, jossa vallan käyttö voi parhaimmillaan olla vapauttavaa. Tällaisia kohtaamisen alueita on monia: erilaisesta neuvonta- ja auttamistyöstä aina saattohoitoon ja kuoleman kohtaamiseen asti. 


\section{Tutkijan sosiaalinen vastuu}

Kriittiset aikuiskasvatuksen tutkijat ovat tehneet tutkimusta muun muassa rakenteellisista seikoista, kuten aikuisten osallistumisesta ja havainneet niin sanotun Matteus-efektin eli koulutuksen kasautumisen niille, joilla on jo ennestään hyvä koulutus ja taloudellinen asema. Lisäksi he ovat analysoineet aikuiskoulutuspolitiikan rakennemuutoksia, etenkin siirtymää tasa-arvon ajasta markkinoiden aikaan.

Paikallishankkeisiin kiinnittyneen toimintatutkimuksen ja rakenteellisen tutkimuksen lisäksi tutkijat ovat kehitelleet teoriaa, jossa on yhdistetty kahden muun lähestymistavan näkökulmat. Tavoitteena on ollut näkemys, jossa aikuisten oppimiskokemukset tuodaan yhteiskuntateoreettiseen kokonaisyhteyteen. Tässälähestymistavassa on toisin sanoen pyritty ylittämään yksilön ja ympäristön välinen kahtiajako ja korvaamaan se kokemuksen käsitteellä ja toiminnan näkökulmalla. Tällöin myös kasvatustiedettä pitkään hallinnut yksilöpsykologinen oppimisen tutkimus on vaihdettu oppimisen sosiaalisten edellytysten ja poliittisten yhteyksien tutkimukseen. Näin tutkijat ovat edenneet yksilön ajattelun tutkimuksesta inhimillisten tekojen ja toiminnan sekä näiden yhteiskunnallisten seurausten tutkimiseen.

Aikuiskasvatuksen tutkijan kannalta kriittisen teorian mukainen aikuiskasvatus tarkoittaa myös uuden tutkimusasenteen omaksumista. Ulkopuolisen tarkkailijan itsekeskeinen näkökulma vaihtuu sosiaalisesti vastuullisen, muihin ihmisiin yhteydessä olevan ihmisen näkökulmaksi (Shotter 1977, 114). Tämä auttaa myös kriittisten tutkimuskysymysten muotoilussa. Ja haluaisinkin ehdottaa, että ottaisimme sosiaalisesti ja poliittisesti tyhjän oppimisen käsitteen sijasta käyttöön sellaiset käsitteet kuin kasvatus ja yhteistoiminta sekä kunnioitus ja kuunteleminen, jotka osoittavat oppimisen yhteisöllisen alkuperän.

Nämä käsitteet auttavat tarttumaan sellaisiin tutkimus- ja kehittämistehtäviin, joilla lisätään elämän sosiaalista, kulttuurista ja poliittista mielekkyyttä. Ajatelkaamme esimerkkinä vanhenemista ja siihen liittyviä sivistyksellisiä kysymyksiä, jotka jokainen kohtaa ajallaan. Aikuiskasvatuksen tutkija voisi kysyä, millainen on se yhteiskunta, jossa eletään sivistyksellisesti täysipainoista vanhuutta?

Vastaaviin kysymyksiin voi havahtua muinakin ikäkausina, esimerkiksi keski-iässä, kun lap- siaan kasvattaen ja vanhenevista sukupolvista huolehtien huomaa kenties ensimmäistä kertaa elämänhorisonttinsa ääriviivat ja tajuaa, että "kuulaita syyspäiviä, kesäiltoja, keväitä tai tähtikirkkaita pakkasöitä on jäljellä hyvinkin rajallinen määrä" (Raittila 2006, 61). Tämäntapaisista pohdinnoista aikuiskasvatuksen tutkijan on luonteenomaista lähteä liikkeelle laajentaen kysymyksiä yksilöstä yhteiskuntaan ja yksityisestä yleiseen.

Sivuhuomautuksena sanottakoon, että tällaisten mielen sisäisten ja ulkoisten kokemusten tutkimuspiiriin sopivat myös työelämään ja sen kehittämiseen liittyvät kysymykset, mikäli työn käsite määritellään laajasti ja palkkatyötä tarkastellaan "vastuurationaalisuuden" hengessä pitäen silmällä kaikkien työntekijöiden hyvinvointia ja oikeudenmukaista kohtelua (ks. myös Hart 1995; Mojab 2001).

\section{Oppimisen solidaarisuus}

Yhteiskuntakriittisessä tehtävässään tutkija on jossain määrin aina autodidaktikko, itseoppija. Kuten sosiologi Matti Virtanen muistuttaa: "Jos yhteiskuntatutkija ei ymmärrä, millaisista aineksista oman mielen linssi on rakentunut, ei hän myöskään ymmärrä niitä kuvia, kuvajaisia ja niiden välisiä suhteita, joita tuo linssi mieleen heittää" (Virtanen 2004). Joskus on myös osattava vaihtaa linssiä, jonka läpi katselee. Mielen linssiään voi kehittää paitsi tutkimustiedolla, myös erilaisilla kehon ja mielen harjoituksilla tai vaikkapa taiteen tai muun sisältörikkaan toiminnan parissa. Aikuiskasvatuksen tutkijan on parhaimpina hetkinään mahdollista kokea työnsä taiteilijan herkkyydellä olematta kuitenkaan taiteilija. Ja vaikkei näin kokisikaan, omaan ammatilliseen ja yhteiskunnalliseen kasvuun sopii ammentaa taiteilijoiden tavasta hyödyntää elämänkokemustaan. Esimerkiksi sosiologi Robert Nesbit sanoo sosiologian olevan yhtä paljon taidetta kuin tiedettä, ja kumpuavan samasta luovuuden lähteestä kuin musiikki ja maalaustaide tai teatteri ja kirjallisuus (Nesbit 1976, 9).

Tämänkaltaisia luovaa mielikuvitusta ruokkivia kasvuprosesseja kannattaa mielestäni tavoitella kaikessa yliopistotyössä; tutkimuksessa, opetuksessa ja opiskelussa.

Yksi mahdollisuus on lisätä yhteistyöhön perustuvia monitieteisiä tutkimushankkeita ja kehittää yhteistoiminnallisia opetusmenetelmiä 
(Bruffee 1999) niiden loputtomien kirjatenttien vastapainoksi, joilla sivuaineita tätä nykyä opiskellaan. Toiseksi yhteiskuntatieteellistä mielikuvitusta voidaan lisätä vapaalla kansalaiskeskustelulla, johon tuskin kuitenkaan kannattaa sekaantua, jos uskoo todellisuuden jäsentyvän vain jonkin tietyn periaatteen mukaan, olipa se sitten jumalan oletettu tahto tai tieteen lainalaisuus (ks. Karkama 1998, 25).

Kun kirjailija Hannu Raittila kritisoi Finlandia-palkintopuheessaan vuonna 2001 kirjallisuudentutkimusta ja kritiikkiä, käskivät jotkut alan tutkijoista häntä tukkimaan suunsa, joutuivatpa jotkut kuulemma häpeämään silmät päästään kirjailijan puutteellista lukeneisuutta (Raittila 2006, 85).

Aikuiselämän ja kasvatuksen kysymyksissä ei tällaista pelkoa onneksi ole; niissä maallikot ovat vain harvoin erotettavissa niin kutsutuista asiantuntijoista (ks. myös Welton 1995). Perinteisesti aikuiskasvatuksen didaktiikassa on kunnioitettu oppilaiden aikuisuutta ja painotettu opettamisen sijasta heidän oppimisensa helpottamista. Vastaavasti tutkimuksessa näyttäisi olevan entistä keskeisempää tarkastella sitä, kuinka aikuisia ohjataan sellaiseen pohtivaan oppimiseen tai "kriittiseen reflektioon", jonka avulla löytää uusia ja vaihtoehtoisia ratkaisuja vanhoihin kysymyksiin. (Jarvis 1993, 184-185.) Painotus on nimenomaan aikuisten omaehtoisen ja yhteistyöhön perustuvan oppimisen tutkimuksessa ja tukemisessa. Ja tämä koskee myös yliopisto-opiskelua.

Aikuiskasvatuksen tutkijan on tutkimusalansa yleisluonteisuudesta johtuen luettava ja kirjoitettava paljon ja kaikenlaista, ja osallistuttava silmät ja korvat auki kulttuurielämään sen moninaisuus huomioiden. Näin voi tavoittaa myös aikuisten kasvun uudet muodot, jotka eivät rajoitu järjestettyihin aikuisopintoihin. Tärkeät tutkimusteemat saattavat yhä useammin löytyä kulutuskeitaiden kansanmarketeista, television ja sohvan välistä tai internetin keskustelu- ja fanipalstoilta. Näissähän me aikuiset näytämme joka tapauksessa aikaamme viettävän.

Koska aikuiskasvatus on useiden lähitieteenalojen oppeja soveltava ja niiden tuloksille omaperäisesti rakentuva käytäntösuuntautunut tiede, sen tutkija joutuu liikkumaan eri tieteenaloja yhdistävän sillan lisäksi aikuiskasvatuksen käytäntöjen maaperällä niiden muutoksia hahmottaen ja kenties toiminnan (poliittisiin ja ideologi- siin) perusteisiin tutkimuksellaan vaikuttaen. Hän työskentelee tieteen ja käytännön kentillä universaalia ja orgaanista sekä yleistä ja paikallista tarkastelutapaa yhdistäen. Näin tutkimustyöllä on mahdollista tukea niin sanotun suuren yleisön yhteiskunnallista tietoisuutta, mutta myös pienten vastayleisöjen harjoittamaa niin kutsuttua suoraa toimintaa, jolla vastustetaan yhteiskunnallisia epäkohtia (ks. Burawoy 2005, 430-431).

Kirjoittaessani kirjaa Radikaali kasvatus (Suoranta 2005), alaotsikoltaan Kohti kasvatuksen poliittista sosiologiaa, mielessäni olivat nimenomaan nämä pienen vastayleisön kansalaisaktivistit, jotka itsensä ja usein tulevaisuutensakin peliin pannen kamppailevat yhteiskunnan rakenteellista ja symbolista väkivaltaa vastaan samalla poliittista kokemustaan kartuttaen (viite 1). He takaavat osaltaan suomalaisen kansalaisyhteiskunnan ja demokratian toiminnan, vaikka kansalaismielipide ei aina olekaan heidän puolellaan.

IIman kriittistä pohdintaa kansalaisaktivistien poliittinen oppiminen saattaa kuitenkin jäädä vain toiminnaksi toiminnan vuoksi. Siksi kriittisen teorian suuntaisesti ajattelevan tutkijan kannattaa osallistua sellaisten tutkimusmenetelmien kehittelyyn, joilla inmisten omat elämäntulkinnat ja kokemukset voidaan tuoda mahdollisimman rikkaina teorian yhteyteen ( $k s$. van Manen 1990; Yorks 2005). Tällaisella toiminnan ja teorian dialogisella yhdistämisellä vältetään harkitsematon aktivismi ja teoreettinen verbalismi (Freire 2005, 95-96). Näin luodaan myös opetuskäytäntöjä, jolla vahvistetaan opettajien ja opiskelijoiden toimintamahdollisuuksia ja lisätään välineitä erivertaisuuden vähentämiseksi.

Tamperelaisrunoilija Risto Ahti kirjoittaa: "Joskus olen ajatellut, että suomenkieli herää vasta sitten, kun puhuja ottaa puheestaan syvästi täyden ihmisen vastuun" (Ahti 2006). Näin ajatellen tutkimuksen arvo ratkeaa ehkä vasta silIoin, kun tutkija osaa mitata sanansa ihmisyyden asteikolla kritiikin ja toivon näköaloja luoden. Tässä suhteessa aikuiskasvatuksen tutkimus voi olla myös sellaista "esilläpitotutkimusta" (ks. Mäkelä 2000), jolla taataan, ettei jokin inmisyyden kannalta olennainen teema pääse unohtumaan.

\section{Kokemuksen todistusvoima}

Tunnettu ranskalaissosiologi Pierre Bourdieu ryh- 
tyi vanhoilla päivillään yhteiskunnalliseksi aktivistiksi puhuen tutkijan kriittisestä vastuusta ja kirjoittaen monissa yhteyksissä "osallistuvan tieteen" puolesta. Mutta niin kuin Bourdieu itse kirjoittaa, hänellä ei ollut turhia kuvitelmia omasta vaikutuksestaan poliittisena toimijana: "Minulla ei ole juurikaan taipumusta profetioihin ja olen aina kavahtanut tilanteita, joissa olosuhteet tai solidaarisuusnäkökohdat olisivat voineet houkutella ylittämään asiantuntemukseni rajat" (emt., 17). Väärinkäsitysten välttämiseksi Bourdieu muisti myös korostaa, ettei tutkijan, taiteilijan tai kirjailijan puuttuminen politiikkaan tee hänestä poliitikkoa; hän vain "hyödyntää poliittisessa kamppailussa erityisiä kykyjään ja auktoriteettiaan ja ammattinsa harjoittamiseen liittyviä arvoja kuten totuutta ja puolueettomuutta" (Bourdieu 2001, käännöstä muutettu).

Mutta juuri nuo tutkimusyhteisön jakamat arvot, totuus ja puolueettomuus, antavat tarvittaessa mahdollisuuden sitoutuneeseen poliittiseen toimintaan ja pakottavat opettamaan sellaista aikuiskasvatuksen teoriaa, jossa vastustetaan kaikenlaisia teknokratian muotoja. Niiden ylpeyden aiheekseen nostaman abstraktin ja silvotun kielen tilalle sitoutuneiden tutkijoiden "kollektiivinen intellektuelli" asettaa sellaiset tiedon muodot, jotka antavat arvoa ihmisille ja heidän kohtaamalleen todellisuudelle (Bourdieu 1999, 48).

Ja jos ajatellaan, että sanat ovat todellisuuden hahmottamisen ja luomisen instrumentteja, toisaalla hallitsemisen ja toisaalla rakkauden välikappaleita, aikuiskasvatuksen tutkijan tehtävä on sellaisten tulkintojen hahmotteleminen, joilla riitautetaan olemassa olevia ennakkoluuloja, ja joilla korjataan vallassa olevia käsityksiä ja käytäntöjä. Lisäksi tavoitteena olkoon yhteistoimintaan, välittämiseen ja kriittiseen toivoon perustuva "sydämen metodologia", jonka suuntaan voimme lähteä siitä missä nyt olemme: käyttäen kriittisesti ja valikoivasti olemassa olevia ideoita ja hyödyntämällä kokemuksen todistusvoimaa (Toulmin 1998, 336).

Kirjoitus perustuu Tampereen yliopistossa 15.12.2006 pidettyyn virkaanastujaisesitelmään.

\section{Viite}

(1) 1990-luvun liikehdintään, tai "radikaaliin vastakulttuuriseen protestiin", kuului eläinoikeus-, ympäristö-, rauhan-, ihmisoikeus-, kehitys- maa-, anarkisti- ja naisliikkeen esittämiä kysymyksiä (Rasimus 2006, 15).

\section{Kirjallisuus}

Ahti, Risto (2006). Runous on kova koulu. Parnasso 56 (7), 10-12.

Bourdieu, Pierre (1999). Vastatulet. Ohjeita uusliberalismin vastaiseen taisteluun. Suom. TiinaArppe. Otava.

Bourdieu, Pierre (2001). Osallistuvan tieteen puolesta. Suom. Antti Kauppinen. Osoitteessa: http://www.helsinki.fi/ amkauppi/pol/ bourdieu_osallistuvan_tieteen_puolesta.htm (29.9.2006)

Brookfield, Stephen (2005). The Power of Critical Theory. San Francisco: Jossey-Bass.

Bruffee, Kenneth (1999). Collaborative Learning: Higher Education, Interdependence, and the Authority of Knowledge. Baltimore: The Johns Hopkins University Press.

Burawoy, Michael (2005). Response: Public Sociology: Populist Fad or Path to Renewal? The British Journal of Sociology 56 (3), 417-431. http://sociology.berkeley.edu/faculty/burawoy/workingpapers.htm

Cervero, Ronald \& Wilson, Arthur (2001). At the Heart of Practice: The Struggle for Knowledge and Power. Teoksessa Cervero, Ronald $\&$ Wilson, Arthur (toim.). Power in Practice. Adult Education and the Struggle for Knowledge and Power in Society. San Francisco: Jossey-Bass, 1-20.

Ehrnrooth, Jari (1995). Asentoja. Muistelmia nykyajasta. WSOY.

Engels, Friedrich (1886). Ludwig Feuerbach ja klassisen saksalaisen filosofian loppu. http:// wuw.marxists.org/suomi/marx/1886/ 1886 Engels ludwig feuerbach.htm (13.12.2006)

Freire, Paulo (2005). Sorrettujen pedagogiikka. Suom. Joel Kuortti. Toim. Tuukka Tomperi. Vastapaino.

George, Susan (2002). Another World is Possible. The Nation 18.2., Osoitteessa: http:// www.thenation.com/ doc/20020218/george (3.12.2006)

Hart, Mechthild (1995). Motherwork: A Radical Proposal to Rethink Work and Education. 
Teoksessa Welton, Michael (toim.). In Defense of the Lifeworld. Critical Perspectives on Adult Learning. Albany: SUNY Press, 99125.

Harva, Urpo (1974). Akateemisen opettajan tehtävä. Opistolehti 1, 14, 19-20.

Jarvis, Peter (1993). Oppimisen paradokseja myöhäismodernissa. Aikuiskasvatus 13 (3), 181-187.

Karkama, Pertti (1998). Kulttuurija demokratia. SKS.

Mayo, Peter (2003). Marxist Impact on Adult Education. Teoksessa Vassallo, C. \& Thake Vassallo, C. (toim.). The Communist Manifesto. Malta University Press, 49-61.

Mojab, Shahrzad (2001). The Power of Economic Globalization. Deskilling Immigrant Women Through Training. Teoksessa Cervero, Ronald \& Wilson, Arthur (toim.). Power in Practice. Adult Education and the Struggle for Knowledge and Power in Society. San Francisco: Jossey-Bass, 23-41.

Mäkelä, Klaus (2000). Stakes ja valtiollisen tiedontuotannon muutokset. Yhteiskuntapolitiikka 65 (3), 280-281.

Misik, Robert (2006). Marx jokamiehelle. Otava.

Nesbit, Robert (1976). Sociology as an Art Form. London: Oxford University Press.

Raittila, Hannu (2006). Kirjailijaelämää. WSOY.
Rasimus, Ari (2006). Uudet liikkeet. Radikaali kansalaisaktivismi 1990-luvun Suomessa. Tampere: TUP. http://acta.uta.fi/ teos.phtml?10894

Shotter, John (1977). Psykologian ihmiskäsityksiä. Suom. Manu Jääskeläinen. Weilin+Göös.

Suoranta, Juha (2005). Radikaali kasvatus. Kohti kasvatuksen poliittista sosiologiaa. Gaudeamus.

Toulmin, Stephen (1998). Kosmopolis. Suom. Matti Kinnunen. WSOY.

van Manen, Max (1990). Researching Lived Experience. New York: SUNY.

Yorks, Lyle (2005). Adult Learning and the Generation of New Knowledge and Meaning: Creating Liberating Spaces for Fostering Adult Learning Through Practitioner-Based Collaborative Action Inquiry. Teachers College Record 107 (6), 1217-1244. http:// www.tcrecord.org/ Content.asp?ContentID=11909 (12.12.2006)

Virtanen, Matti (2004). Kuva ja kuvajainen (arvostelu kirjasta Eskola, Antti \& Kurki, Leena: Miehestä mittaa). Helsingin Sanomat 20.11. Osoitteessa: http://www.hs.fi/tulosta/ HS20041120SI1KU02h9u (21.11.2006)

Welton, Michael (1995). Amateurs out to Change the World: A Retrospective on Community Development. Convergence 28 (2), 49-61. 